\title{
RAPE DURING
}

CIVIL WAR 



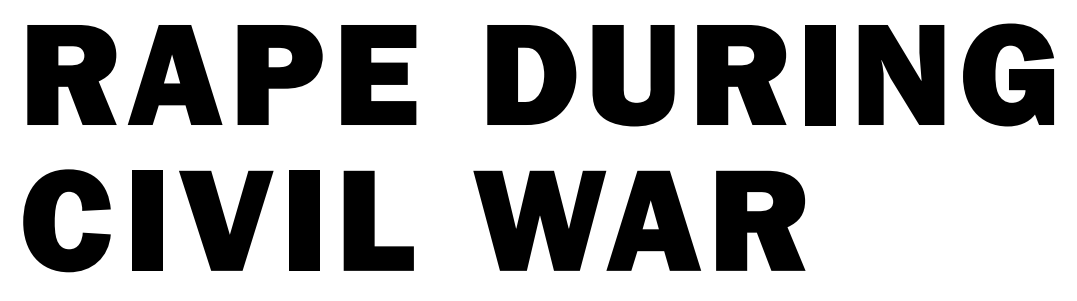

Dara Kay Cohen 


\section{Copyright () 2016 by Cornell University}

All rights reserved. Except for brief quotations in a review, this book, or parts thereof, must not be reproduced in any form without permission in writing from the publisher. For information, address Cornell University Press, Sage House, 512 East State Street, Ithaca, New York 14850.

First published 2016 by Cornell University Press

First printing, Cornell Paperbacks, 2016

Printed in the United States of America

Library of Congress Cataloging-in-Publication Data

Names: Cohen, Dara Kay, 1979- author.

Title: Rape during civil war / Dara Kay Cohen.

Description: Ithaca ; London : Cornell University Press, 2016.|

Includes bibliographical references and index.

Identifiers: LCCN 2016013022 | ISBN 9781501702518 (cloth : alk. paper) |

ISBN 9781501705274 (pbk. : alk. paper)

Subjects: LCSH: Rape as a weapon of war. | Soldiers—Sexual behavior. |

Civil war.

Classification: LCC HV6558 .C643 2016 | DDC 362.883—dc23

LC record available at http://lccn.loc.gov/2016013022

Cornell University Press strives to use environmentally responsible suppliers and materials to the fullest extent possible in the publishing of its books. Such materials include vegetable-based, low-VOC inks and acid-free papers that are recycled, totally chlorine-free, or partly composed of nonwood fibers. For further information, visit our website at www.cornellpress.cornell.edu.

Cloth printing

Paperback printing $\begin{array}{llllllllll}10 & 9 & 8 & 7 & 6 & 5 & 4 & 3 & 2 & 1\end{array}$

$\begin{array}{llllllllll}10 & 9 & 8 & 7 & 6 & 5 & 4 & 3 & 2 & 1\end{array}$ 
To Barry and Layla 
